DOI: $10.17516 / 1998-2836-0218$

УДК 542.06:543.05:543.54

\title{
Device and Method of Sample Preparation \\ for Gas Chromatographic determination \\ of Volatile Organic Compounds in Complex Matrices
}

\author{
Andrei V. Oberenko ${ }^{a *}$, \\ Sergey V. Kachin ${ }^{b}$ and Sergey A. Sagalakov ${ }^{b}$ \\ ${ }^{a}$ Criminal Expertise Centre of Directorate for Law Enforcement \\ in Transport Means of Russian Ministry of Internal Affairs \\ for Siberian Federal District \\ Krasnoyarsk, Russian Federation \\ ${ }^{b}$ Siberian Federal University \\ Krasnoyarsk, Russian Federation
}

Received 30.12.2020, received in revised form 10.01.2021, accepted 21.02.2021

\begin{abstract}
A device and a method for sample preparation have been developed, which make it possible to implement successive stages of thermal separation of volatile components from a solid (liquid) matrix, their capture from the gas phase by a solid sorbent, and liquid microextraction of sorbates for further gas chromatographic analysis. The device and the algorithm of its application for $\mathrm{GC}-$ MS determination of a number of volatile organic compounds from matrices with complex chemical composition have been tested.
\end{abstract}

Keywords: sample preparation, sample preparation device, headspace analysis, sorption, liquid microextraction, volatile organic compounds, GC, GC-MS.

Citation: Oberenko A.V., Kachin S.V., Sagalakov S.A. Device and method of sample preparation for gas chromatographic determination of volatile organic compounds in complex matrices, J. Sib. Fed. Univ. Chem., 2021, 14(1), 82-90. DOI: $10.17516 / 1998-2836-0218$

(C) Siberian Federal University. All rights reserved

This work is licensed under a Creative Commons Attribution-NonCommercial 4.0 International License (CC BY-NC 4.0).

* Corresponding author E-mail address: krasandrew@mail.ru

ORCID: 0000-0002-1156-9644 (Oberenko A.); 0000-0002-7162-449X (Kachin S.); 0000-0002-6459-8852 (Sagalakov S.) 


\title{
Устройство и методика пробоподготовки образцов \\ для газохроматографических исследований \\ с использованием парофазной сорбционной \\ микроэкстракции компонентов
}

\author{
А. В. Оберенко ${ }^{a}$, С. В. Качин ${ }^{\sigma}$, С. А. Сагалаков ${ }^{\sigma}$ \\ аЭкспертно-криминалистический цеентр Управления \\ на транспорте МВД России по Сибирскому федеральному округу \\ Российская Федерация, Красноярск \\ ${ }^{\sigma}$ Сибирский федеральный университет \\ Российская Федераиия, Красноярск
}

\begin{abstract}
Аннотация. Разработано устройство и методика пробоподготовки образцов, позволяющие реализовать последовательные стадии термического выделения летучих компонентов из твердой (жидкой) матрицы, их улавливание из газовой фазы твердым сорбентом и жидкостную микроэкстракцию сорбатов для дальнейших газохроматографических исследований. Проведена апробация устройства и алгоритма его применения для ГХ- и масс-спектрометрических определений ряда летучих органических соединений из сложных по своему химическому составу матриц.
\end{abstract}

Ключевые слова: пробоподготовка, устройство для пробоподготовки, парофазный анализ, сорбция, жидкостная микроэкстракция, летучие органические соединения, газовая хроматография, хромато-масс-спектрометрия.

Цитирование: Оберенко, А. В. Устройство и методика пробоподготовки образцов для газохроматографических исследований с использованием парофазной сорбционной микроэкстракции компонентов / А.В. Оберенко, С.В. Качин, С. А. Сагалаков // Журн. Сиб. федер. ун-та. Химия, 2021, 14(1). С. 82-90. DOI: 10.17516/1998-2836-0218

\section{Introduction}

The successes of modern gas chromatography (GC) are largely associated with the development of efficient methods of sample preparation: processes and devices [1-3]. Isolation and concentration of target components from matrices with complex chemical composition can provide a significant increase in the selectivity and sensitivity of GC determinations already at the sampling stage. For example, in headspace sampling, the gas phase above the object, which contains volatile compounds, is analyzed, which reduces the influence of matrix effects. The use of microextraction can significantly reduce the volume of the analyzed sample and increase the concentration of the component. The efficiency of microextraction has been demonstrated on numerous examples in the «Headspace» (HS) sample preparation methods for the separation of volatile and semi-volatile components in a vapor state under dynamic or static conditions from complex matrices such as biological samples, pharmaceuticals, food products, soils [4-8]. The following combinations of processes and devices 
Table 1. Limitations and disadvantages of HS sample preparation methods

\begin{tabular}{|c|l|}
\hline Method & \multicolumn{1}{c|}{ Method Limitations and Disadvantages } \\
\hline SPME & $\begin{array}{l}\text { fragility of quartz fibers, degradation of polymer coatings when using metal carriers, } \\
\text { rather high cost of consumables that are not produced in Russia. }\end{array}$ \\
\hline $\begin{array}{c}\text { ITSPME } \\
\text { SPDE } \\
\text { PNME }\end{array}$ & $\begin{array}{l}\text { Small capacities and a limited set of extraction phases, decomposition of the polymer } \\
\text { coating during desorption, lack of commercially available models. }\end{array}$ \\
\hline SDME & $\begin{array}{l}\text { Instability of a solvent droplet and the possibility of its detachment from the needle, } \\
\text { solvent evaporation at high temperatures. }\end{array}$ \\
\hline
\end{tabular}

were used: static (SPME) [9] and dynamic (SPDE) [10] solid phase microextraction, in-tube solidphase microextraction (ITSPME) [11], single dropmicroextraction (SDME) [12] hollow fiber-based liquid phase microextraction (HF-LPME) [13], sorbent-packedneedle-trap device (SP-NTD) [14]. Despite the advantages of the methods described [9-14], they are also not devoid of a number of limitations and disadvantages (Table 1).

The aim of this work was to develop a combined method for sample preparation, including the processes of vapor-phase separation of volatile components, their capture from the gas phase with a solid sorbent and subsequent liquid microextraction of sorbates, as well as the development of a corresponding device.

\section{Experimental}

\section{Materials and methods}

Devices and equipment: Chromatograph «Kristall 5000.2» (Russia) in the following configuration: quartz capillary column $(\mathrm{L}=20 \mathrm{~m}, \varnothing=0.25 \mathrm{~mm})$ with dimethylsilicone phase containing $5 \%$ phenyl groups (HP 5MS type); quadrupole mass spectrometric detector «ISQ». Thermostat EB-18 Jouan (France). Measurement conditions: ionization by electron impact (energy $70 \mathrm{eV}$ ); temperature of the evaporator and detector interface $-280^{\circ} \mathrm{C}$; programming the temperature of the column thermostat from $50{ }^{\circ} \mathrm{C}$ (initial) to $200{ }^{\circ} \mathrm{C}$ (final), the rate of rise temperature is $20{ }^{\circ} \mathrm{C} / \mathrm{min}$; holding time at final temperature $5 \mathrm{~min}$; carrier gas - helium; carrier gas flow rate $1.0 \mathrm{ml} / \mathrm{min}$; sample injection mode - split flow (Split 20: 1), sample injection volume $1 \mu \mathrm{l}$. Reagents Methanol (Merck, chemically pure grade), dichlomethane (analytical grade, OOO KomponentReaktiv), trichloromethane (analytical grade, ZAO Vekton), carbon tetrachloride (analytical grade), ZAO EKOS-1), hexane (analytical grade, ZAO Vekton), diethylamine (analytical grade, ZAO Mosreaktiv), triethylamine (analytical grade, ZAO Mosreaktiv), tetrahydrofuran (analytical grade, OOO Komponent-Reaktiv), dioxane (analytical grade, OOO Komponent-Reaktiv), toluene (analytical grade, ZAO Baza No. 1 Khimreativov), silica gel ASKG, fraction 0.2-0.5 mm, helium grade «A» (OJSC Gazprom).

\section{Device for conducting vapor-phase sorptivemicroextraction}

The device for conducting vapor-phase sorptivemicroextraction consists of a hermetically sealed vial made of thermally stable glass with an analyzed sample and a conical glass insert with a hole in the upper part, at the bottom of which there is a sorbent (Fig. 1). 


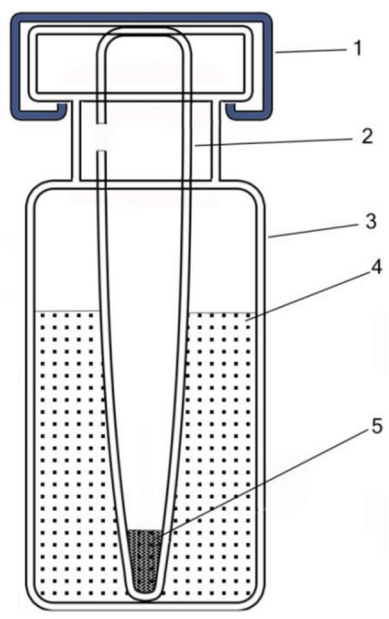

Fig. 1. Device for vapor-phase sorption microextraction of samples. Crimp sealed lid -1 , glass insert -2 , vial -3 , sample -4 , sorbent -5

The sample to be analyzed is placed in the vial in the form of a solution or a solid phase ground to a powder form. Next, a glass insert with the selected sorbent is placed in the vial. The vial is sealed with a crimp hermetic lid and placed in a heating device for thermal separation of volatile components from the sample matrix into the gas phase with their subsequent sorption with a solid sorbent. Upon completion of these processes, the vial is removed from the heating device and cooled to room temperature. The sorbent is treated with a certain volume of solvent by using a microsyringe, and the resulting extracts are subjected to GC-MS studies.

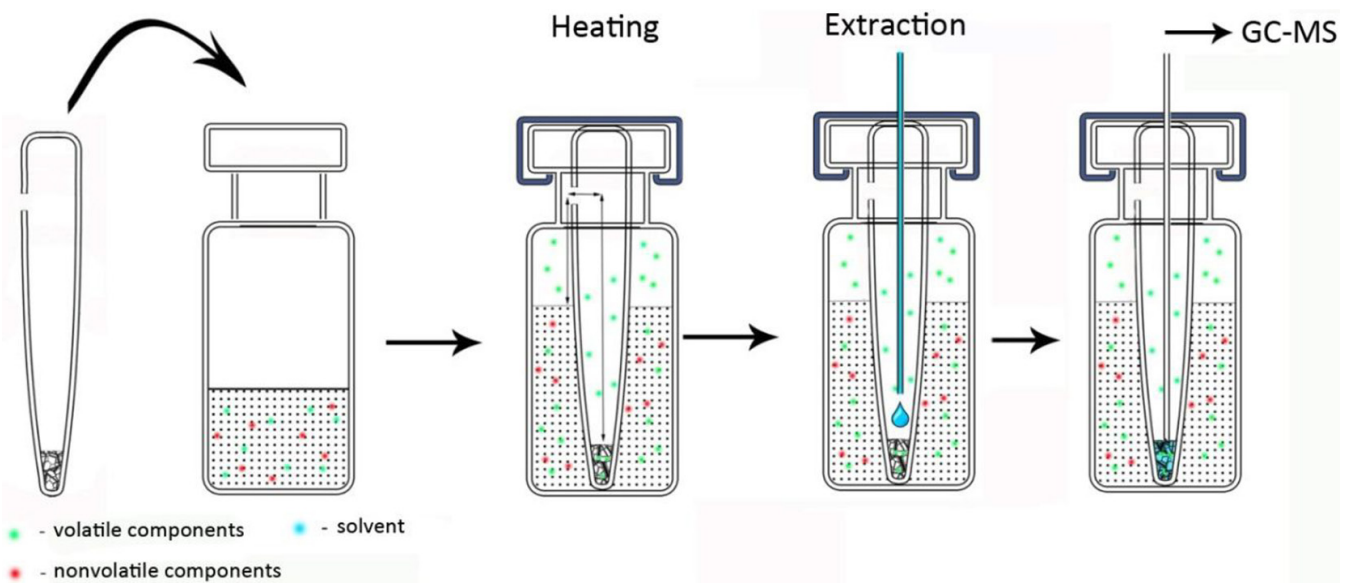

Fig. 2. The principle of operation of the device for conducting vapor-phase sorption microextraction

\section{Sample preparation}

Model solutions of volatile organic compounds of various natures in methanol were prepared (Table 2). 
Table 2. Concentrations of model solutions

\begin{tabular}{|c|c|c|c|c|}
\hline \multirow{2}{*}{ Component } & \multicolumn{4}{|c|}{ Concentration, g/L } \\
\cline { 2 - 5 } & Solution № 1 & Solution № 2 & Solution № 3 & Solution № 4 \\
\hline dichlomethane & 5,3 & 0,53 & 0,11 & 0,053 \\
\hline hexane & 2,6 & 0,26 & 0,05 & 0,026 \\
\hline diethylamine & 2,8 & 0,28 & 0,06 & 0,028 \\
\hline trichloromethane & 5,9 & 0,59 & 0,12 & 0,059 \\
\hline tetrahydrofuran & 3,6 & 0,36 & 0,07 & 0,036 \\
\hline carbon tetrachloride & 6,4 & 0,64 & 0,13 & 0,064 \\
\hline triethylamine & 2,9 & 0,29 & 0,06 & 0,029 \\
\hline 1,4-dioxane & 4,1 & 0,41 & 0,08 & 0,041 \\
\hline toluene & 3,5 & 0,35 & 0,07 & 0,035 \\
\hline
\end{tabular}

\section{Results and their discussion}

To check the possibility of separating and detecting the analyzed compounds, the model mixtures were chromatographed under the above conditions. Component peaks were identified by comparing the obtained chromatograms, mass spectra of the studied and standard samples using the literature data and the NIST14 library. The search and comparison of mass spectra was carried out using the NIST MS Search 2.0 program. The percentage of coincidence of the experimental mass spectra with the library ones was at least $90 \%$. It was found that with the selected chromatographic parameters, an effective separation of the mixture components is achieved. Although a decrease in the split of the flow gives a slight increase in sensitivity, it leads to a deterioration in the chromatographic separation of the components. Atypicalchromatogram of a model mixture is shown in Fig. 3.

In order to assess the applicability of the device for the separation of volatile components, the operations described above were performed. The vials contained $1 \mu 1$ of model solution 2 . Silica gel ASKG, fraction $0.2-0.5 \mathrm{~mm}$, weight $10 \mathrm{mg}$ was used as a sorbent. The choice of the sorbent was determined by its widespread use, low price, and versatility for various classes of compounds. Fraction $0.2-0.5 \mathrm{~mm}$ allows the selection of the extract with a chromatographic syringe without filtration, since the size of the granules is larger than the inner diameter of the needle $(0.1 \mathrm{~mm})$. The vials were hermetically sealed and kept for 30 minutes at $115{ }^{\circ} \mathrm{C}$. The choice of the heating temperature was determined by the boiling point - toluene $\left(110.6^{\circ} \mathrm{C}\right)$ - the highest-boiling component. The extraction of sorbates was carried out with $30 \mu \mathrm{L}$ of methanol for $30 \mathrm{~min}$.

Chromatograms of extracts and model solutions with the addition of methyl stearate $(3.5 \mathrm{~g} / \mathrm{L})$ as a nonvolatile component are shown in Fig. 4. In both cases, the chromatographic peaks of the initial and isolated volatile compounds were recorded, which indicates the fundamental possibility of using this device in solving the problem. Methyl stearate was not found in the extract.

As a result of the study, the optimal parameters of the sample preparation process for the used set of compounds using this device were established: heating time - $15 \mathrm{~min}$; cooling the vial to room temperature; extraction time $30 \mathrm{~min}$ under static conditions. This achieves quantitative isolation of the compounds under study. The relative standard deviations of the peak areas for solutions 1-4 (Table 2) at $(\mathrm{n}=5)$ does not exceed 0.05 . The calculated detection limits, based on the signal-to-noise 


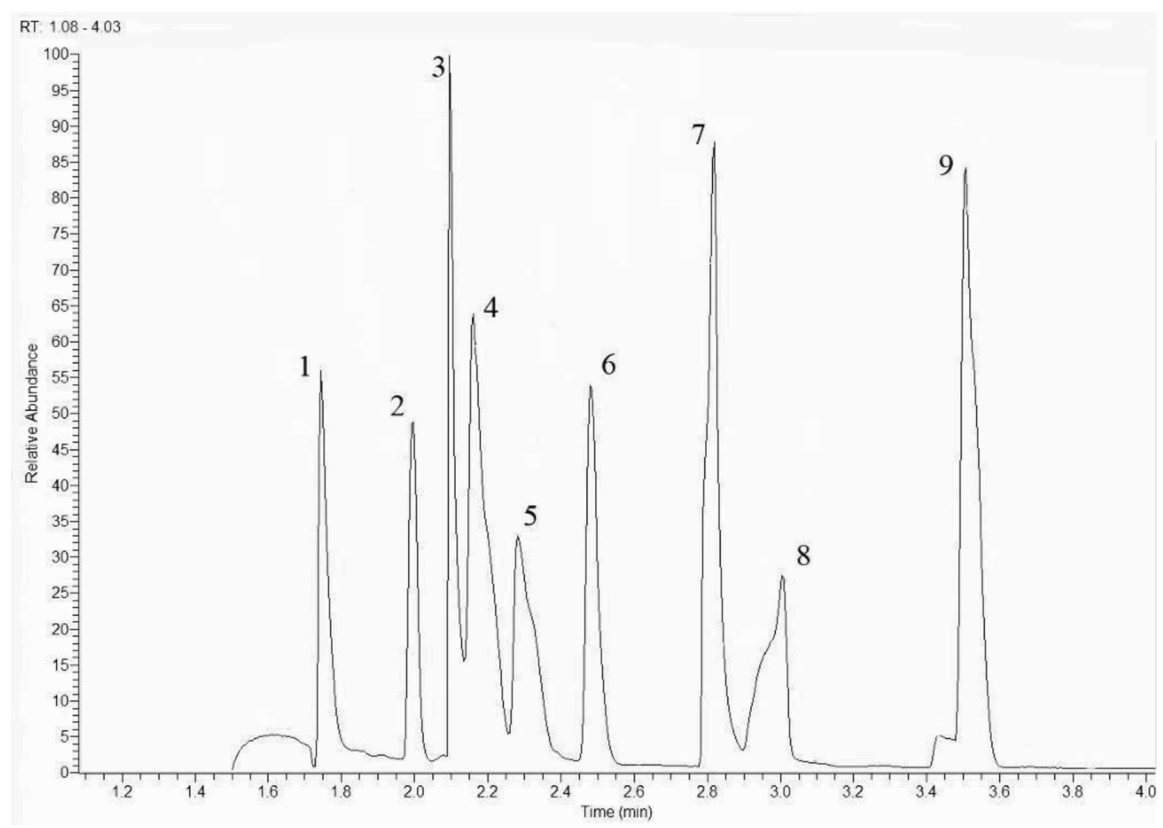

Fig. 3. Fragment of a typical chromatogram on the total ionic current of the model mixture: 1 - dichlomethane; 2 hexane; 3 - diethylamine; 4 - trichloromethane; 5 - tetrahydrofuran; 6 - tetrachloromethane; 7 - triethylamine; 8 -dioxane; 9 - toluene

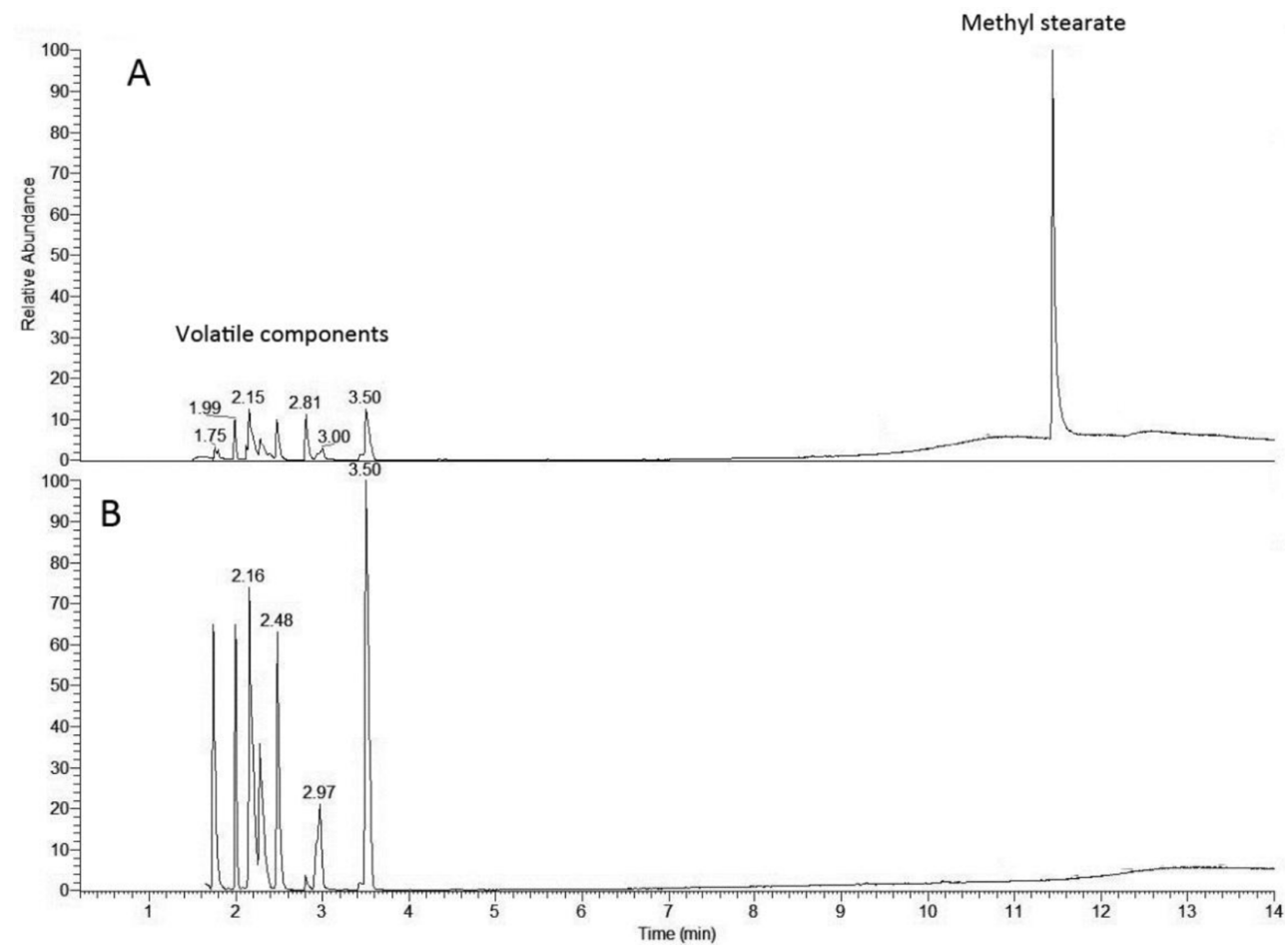

Fig. 4. Chromatograms for the total ionic current of the original solution (A) and the obtained extract (B) 

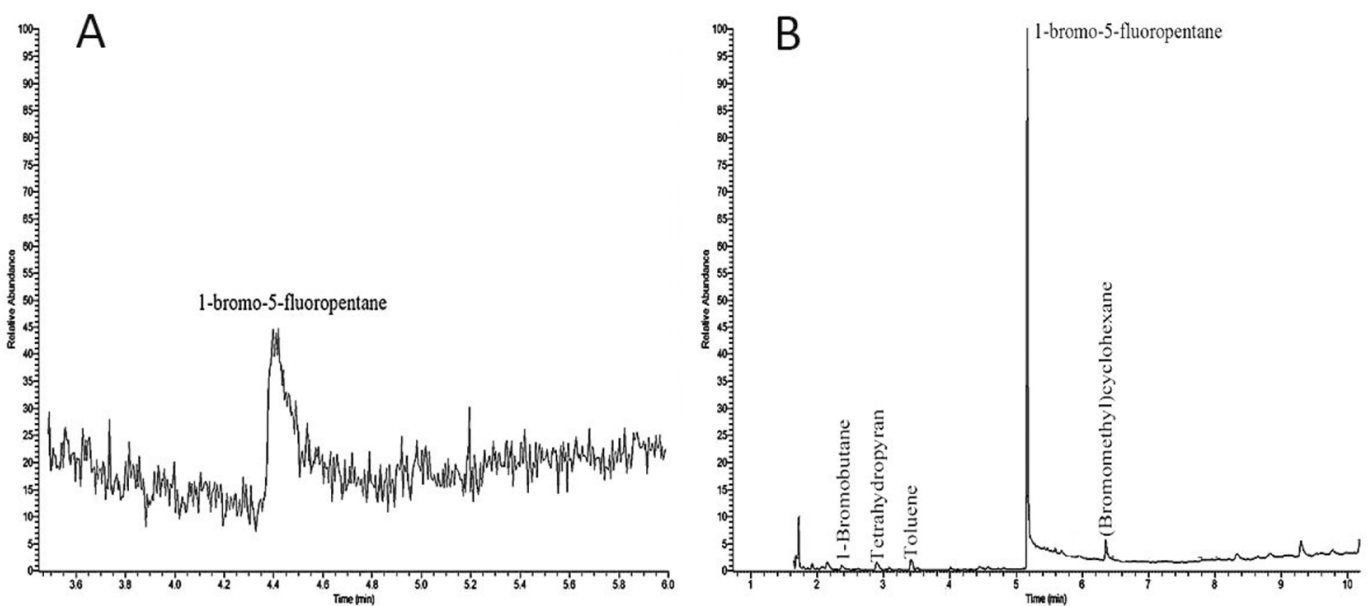

Fig. 5. Chromatograms (TIC) of methanol extracts of the TMCP-2201 sample, obtained: by extraction under standard expert examination conditions (A); using vapor phase sorption microextraction (B)

ratio (for the used model of the mass detector, at least 25: 1), were ( $\mu \mathrm{g} / \mathrm{dm} 3)$ : dichlomethane (31), hexane (51), diethylamine (1500), trichloromethane (29), tetrahydrofuran (23), tetrachloromethane (4), triethylamine (160), 1,4-dioxane (51), toluene (20).

In the described format, the device was successfully tested in the determination of food flavorings for tea [15], flavoring and aromatic additives of chewing gums [16], volatile impurities in synthetic cannabinoids [17]. In Fig. 5, as an example, chromatograms of the total ionic current (TIC) of methanol extracts of an expert sample of the synthetic cannabinoid TMCP-2201 are shown.

The use of vapor-phase sorption microextraction can significantly increase the information content of chromatograms: both in terms of the number of identified compounds and the intensity of chromatographic peaks and the corresponding quality of mass spectra, as can be seen from Fig. 5.

\section{Conclusion}

A device and a method for sample preparation have been developed, including the processes of vapor-phase separation of volatile components from matrices with complex chemical composition, their capture from the gas phase with a solid sorbent and liquid microextraction of sorbates for further gas chromatographic studies. The use of this device in sample preparation of real objects has shown the promise of its use for $\mathrm{GC}$ - and $\mathrm{GC}-\mathrm{MS}$ determination of volatile components.

\section{References}

1. Ramos L. Critical overview of selected contemporary sample preparation techniques. Journal of Chromatography A 2012. Vol. 1221, P. 84-98. https://doi.org/10.1016/j.chroma.2011.11.011

2. Asfaw A. A., Aspromonte J., Wolfs K., van Schepdael A., Adams E. Overview of sample introduction techniques prior to GC for the analysis of volatiles in solid materials. Journal of Separation Science 2018. Vol. 42(1), P. 214-225. https://doi.org/10.1002/jssc.201800711

3. Hansen F. A., Pedersen-Bjergaard S. Emerging extraction strategies in analytical chemistry. Analytical Chemistry 2020. Vol. 92(1), P. 2-15. https://doi.org/10.1021/acs.analchem.9b04677 
4. Dettmer-Wilde K., Engewald W. Practical gas chromatography A Comprehensive Reference. Berlin: Springer, 2014. 902. p. https://doi.org/10.1007/978-3-642-54640-2

5. Soria A.C., García-Sarrió M. J., Sanz M.L. Volatile sampling by headspace techniques. TrAC trends in analytical chemistry 2015. Vol. 71, P. 85-99. https://doi.org/10.1016/j.trac.2015.04.015

6. Kusano M., Mendez E., Furton K. G. Development of headspace SPME method for analysis of volatile organic compounds present in human biological specimens. Analytical and bioanalytical chemistry 2011. Vol. 400(7), P. 1817-1826. https://doi.org/10.1007/s00216-011-4950-2

7. Orazbayeva D. et al. Quantification of BTEX in soil by headspace SPME-GC-MS using combined standard addition and internal standard calibration. Chromatographia 2017. Vol. 80(8), P. 1249-1256. https://doi.org/10.1007/s10337-017-3340-0

8. Reyes-Garces N. et al. Advances in solid phase microextraction and perspective on future directions. Analytical chemistry 2017. Vol. 90(1), P. 302-360. https://doi.org/10.1021/acs. analchem.7b04502

9. Heydari R. Residual solvents determination in pharmaceuticals by static headspace-gas chromatography and headspace liquid-phase microextraction gas chromatography. Analytical letters 2012. Vol. 45(13), P. 1875-1884. https://doi.org/10.1080/00032719.2012.677982

10. Pontes M., Pereira J., Câmara J. S. Dynamic headspace solid-phase microextraction combined with one-dimensional gas chromatography-mass spectrometry as a powerful tool to differentiate banana cultivars based on their volatile metabolite profile. Food chemistry 2012. Vol. 134(4), P. 25092520. https://doi.org/10.1016/j.foodchem.2012.04.087

11. Queiroz M. E. C., de Souza I.D., Marchioni C. Current advances and applications of intube solid-phase microextraction. TrAC Trends in Analytical Chemistry 2019. Vol. 111, P. 261-278. https://doi.org/10.1016/j.trac.2018.12.018

12. Tang S. et al. Single-drop microextraction. TrAC Trends in Analytical Chemistry 2018. Vol. 108, P. 306-313. https://doi.org/10.1016/j.trac.2018.09.016

13. Ghambarian M., Yamini Y., Esrafili A. Developments in hollow fiber based liquid-phase microextraction: principles and applications. Microchimica Acta 2012. Vol. 177(3-4), P. 271-294. https://doi.org/10.1016/j.jpha.2019.12.003

14. Kędziora K., Wasiak W. Extraction media used in needle trap devices - Progress in development and application. Journal of Chromatography A 2017. Vol. 1505, P. 1-17. https://doi. org/10.1016/j.chroma.2017.05.030

15. Оберенко А.В. Хромато-масс-спектрометрическое определение пищевых ароматизаторов чая с их предварительным выделением методом парофазной сорбции. Maтериаль XVI Междунар. конф. студентов, аспирантов и молодых ученых 2020 «Проспект Свободный 2020», Красноярск, СФУ, 2020. С. 692-694. [Oberenko A. V. Chromato-mass spectrometric determination of food flavorings in tea with their preliminary isolation by vapor-phase sorption. Materials of the XVI International Conf. students, graduate students and young scientists "Prospect Svobodny - 2020», Krasnoyarsk, SFU, 2020. P. 692-694. (In Russ.)]

16. Курочкина М.Д., Оберенко А.В. Хромато-масс-спектрометрическое определение пищевых ароматизаторов чая с их предварительным выделением методом парофазной сорбции. Материалы XVI Междунар. конф. студентов, аспирантов и молодых ученых 2020 «Проспект Свободный - 2020», Красноярск, СФУ, 2020. С. 686-688. [Kurochkina M.D., 
Oberenko A. V. Chromato-mass-spectrometric determination of flavoring and aromatic additives in chewing gums with their preliminary isolation by vapor-phase sorption. Materials of the XVI International Conf. students, graduate students and young scientists «Prospect Svobodny-2020», Krasnoyarsk, SFU, 2020. P. 686-688. (In Russ.)]

17. Оберенко А.В., Качин С.В., Сагалаков С.А. Газохроматографическое определение летучих примесей в синтетических каннабиноидах с использованием парофазной сорбционной микроэкстракции. Материаль междунар. научно-практической конф. «Современные проблемы химии, технологии и фармации», Чебоксары, ЧГУ, 2020. С. 186-190. [Oberenko A. V., Kachin S. V., Sagalakov S. A. Gas chromatographic determination of volatile impurities in synthetic cannabinoids using vapor-phase sorption microextraction. Materials of the international scientificpractical conference "Modern problems of chemistry, technology and pharmacy», Cheboksary, ChGU, 2020. P. 186-190. (In Russ.)] 